Title no. 103-S75

\title{
Effect of Duct Type on Shear Strength of Thin Webs
}

\author{
by Aurelio Muttoni, Olivier L. Burdet, and Eckart Hars
}

\begin{abstract}
A series of 16 specimens of concrete web panels $23.6 \times 23.6 \times 4.9 \mathrm{in}$. $(600 \times 600 \times 125 \mathrm{~mm})$ was tested in compression to investigate the effect of the presence of various types of post-tensioning ducts on the strength of the shear-induced compression struts. Most panels were cast in the laboratory, but some were extracted from an actual bridge girder, which had been previously loaded, allowing investigation of the effect of web cracking on the ultimate strength. The presence of a duct in a web, whether injected or not, decreases the compressive strength of the panel. This effect is most pronounced for non-injected ducts, but is also much larger for injected plastic ducts than for injected steel ducts. The effect of web cracking further decreases the strength of web panels containing post-tensioning ducts, and this effect can be estimated using classical strength reduction formulas.
\end{abstract}

Keywords: post-tensioning duct; shear strength; testing; web.

\section{INTRODUCTION}

Post-tensioning is a system for introducing a prestressing force in a structure after the concrete has been cast and hardened. This disposition has the advantage over flat-bed prestressing in that there is no need for massive anchoring blocks, as the tendons are directly stressed against the structure itself. It is also the most practicable solution for the prestressing of castin-place structures, and for ensuring continuity between precast girders. To be able to stress the tendons, however, they need to be separated from the concrete so that large strains can be applied to them. This is usually done by inserting the tendons in ducts that are later filled with an injection grout or by a corrosion-inhibiting grease or wax. The presence of the duct in the web of a girder has an influence on the strength of the section (Fig. 1). Whereas this effect is generally negligible for the bending and axial compressive strength of post-tensioned girders, it can be significant for webs, especially in area of high shear (Fig. 2). This is true whether the duct is left empty, filled with a soft material such as grease, or filled by a stiff injection grout.

\section{RESEARCH SIGNIFICANCE}

The presence of ducts decreases the strength of webs in concrete girders, and current design codes account for this effect. Most test results available at the present time are for corrugated steel ducts, which are increasingly being substituted by high-density polyethylene (HDPE) ducts. This paper presents information on the behavior of web girders with posttensioning ducts using steel or HDPE ducts. The replacement of steel ducts by HDPE ducts decreases the strength of thin webs. This paper also investigates the combined effect of the presence of post-tensioning ducts and of cracking, based on tests performed on specimens extracted from real bridge girders.

\section{INFLUENCE OF PRESENCE OF DUCTS IN CROSS SECTION}

In reinforced and prestressed concrete, shear is carried after cracking by the combined action of inclined concrete struts acting in compression and of stirrups acting in tension. The design shear strength is limited by the strength of either or both components, and it is desired that the compressive strength of concrete be sufficient to avoid a brittle failure mode. As Fig. 2 shows, the inclined concrete compression struts are crossed by the post-tensioning tendons, which decreases their load-carrying capacity. When considering an inclined cross section of a web (Fig. 3(a)), the presence of an empty duct has the effect of deviating the compression field around the void, which induces transverse tensile stresses in the immediate vicinity of the tendon duct. At the other extreme, the presence of a very stiff injected tendon duct (Fig. 3(b)) attracts a large part of the effort, which also induces transverse tensile stresses, at a larger distance from the duct. In addition, if the surface of the duct is smooth, sliding can occur, increasing the splitting effect. In reality, the stiffness of the combined system duct/injection grout/tendon is typically not very large,
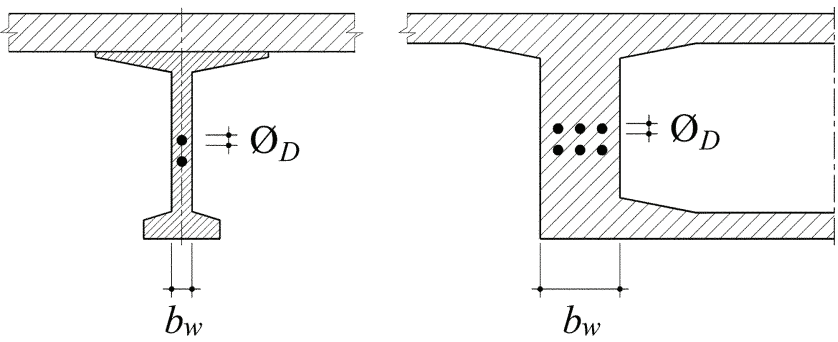

Fig. 1-Disposition of tendon ducts in web of bridge girders.

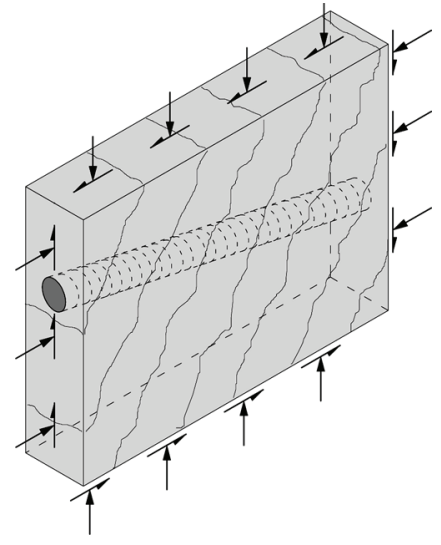

Fig. 2-Tendon duct crossing diagonal shear compression struts.

ACI Structural Journal, V. 103, No. 5, September-October 2006.

MS No. 05-247 received September 9, 2005, and reviewed under Institute publication policies. Copyright (C) 2006, American Concrete Institute. All rights reserved, including the making of copies unless permission is obtained from the copyright proprietors. Pertinen discussion including author's closure, if any, will be published in the July-August 2007 ACI Structural Journal if the discussion is received by March 1, 2007. 
ACI member Aurelio Muttoni is Professor and Head of the Structural Concrete Laboratory, Ecole Polytechnique Fédérale de Lausanne (EPFL), Lausanne, Switzerland. $H$ received his diploma and $P h D$ in civil engineering from the Swiss Federal Institute of Technology in Zurich, Switzerland, in 1982 and 1989, respectively. His research interests include the theoretical bases of the design of reinforced concrete structures, shear and punching shear, fiber-reinforced high-strength concrete, soil-structure interaction, and the conceptual design of bridges.

Olivier L. Burdet is a Senior Researcher and Lecturer at EPFL. He received his diploma in civil engineering from EPFL and his PhD from the University of Texas at Austin, Austin, Tex., in 1983 and 1990, respectively. His research interests include the serviceability behavior of structures and the modeling of the behavior of concrete structures using stress fields.

Eckart Hars is a PhD candidate at EPFL. He received his diploma in civil engineering from the Technische Universität, Hamburg-Harburg, Germany, in 2000. His research interests include the shear behavior of post-tensioned bridge girders.

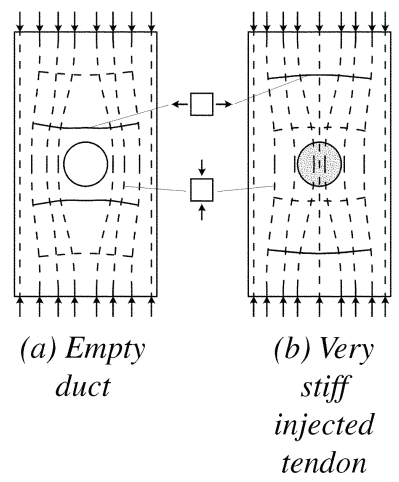

Fig. 3-Effect of presence of ducts in webs on compression field (after Leonhardt ${ }^{2}$ ).

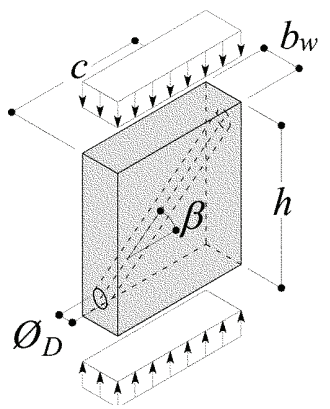

Fig. 4-Web panel with post-tensioning duct.

so that the behavior is an intermediate case, closer to that of an empty duct.

In addition, the presence of post-tensioning ducts in thin webs also has some adverse effects on the quality of the concreting in the immediate vicinity of the duct, with less dense concrete immediately underneath the duct and cracks along the tendon path due to compaction. In the case of injection of the ducts with cement grout, voids are also possible in the upper part of the duct, although this problem does not necessarily appear in zones of high shear in beams where the tendons usually have a larger inclination.

Results from the literature have established that the effect of the presence of post-tensioning ducts in the webs can be significant, especially in cases where the ratio $\delta=\Sigma \varnothing_{D} / b_{w}$ of the total duct section to the overall width of the web is large ${ }^{1-9}$ $(\delta>0.2)$. This effect was neglected in early versions of design codes dealing with post-tensioning, but was later included. ${ }^{10-15}$

In recent years, classical corrugated steel post-tensioning ducts have been increasingly replaced by plastic ducts made of HDPE. These ducts have the advantage of lower friction losses during the tensioning of the cables as well as limiting fretting fatigue effects between the cable and the duct. In addition, this type of duct is required to obtain electrically isolated post-tensioning tendons that are sometimes necessary to completely protect the post-tensioning system from corrosion. The soft material $\left(E_{H D P E} \approx 145-290 \mathrm{ksi}\right.$ $[1000-2000 \mathrm{MPa}])$ that these plastic ducts are made of significantly changes the state of stresses around the injected ducts and further lowers the strength of the web that contains them, with compression struts tangent to the outer surface of the duct. Its low friction coefficient adds to this effect.

\section{STATE OF THE ART AND CURRENT CODE PROVISIONS}

Several researchers have investigated the phenomena related to the presence of empty or injected tendon ducts in the web of girders. ${ }^{1-9}$ Most tests were performed on panel elements subjected to compression (Fig. 4) representing a section of a web subjected to a diagonal compression field induced by shear (Fig. 2). The main parameter for these studies was usually the ratio $\delta$.

Gaynor $^{1}$ tested 66 concrete cylinders, with $\delta$ values between 0.1 and 0.2 , containing solid steel sections instead of a duct and reported a strength reduction compared with plain concrete cylinders.

Leonhardt ${ }^{2}$ investigated 52 panels, some with a lateral eccentricity of the duct and a varying inclination of the duct with respect to the direction of the loading. It was found that both these parameters have little influence on the strength. The presence of two ducts side-by-side in a panel leads in average to a smaller strength reduction than the presence of a single duct of a double diameter, provided that the spacing between ducts is at least one duct diameter. The measurement of the compressive strain distribution over the thickness of the panel at the level of the tendon showed that strains parallel to the load are larger near the duct than on the side surface, regardless of whether the ducts are injected or not. The proposed effective width formula (Eq. (1) and (2)) is a linear function of the duct diameter, distinguishing between injected and empty ducts.

For injected ducts

$$
\eta_{D}=1-\frac{2}{3} \delta
$$

For non-injected ducts

$$
\eta_{D}=1-\delta
$$

where the strength reduction factor $\eta_{D}$ is the ratio of the strength of the specimen with a duct to the strength of an equivalent specimen without a duct. In the case of Leonhardt and several authors, this parameter is often expressed as an effective width factor for the web, which leads to the same result.

Leonhardt also tested specimens with solid steel bars instead of injected ducts. The results were not significantly different, showing that the stiffness of the injected tendon is not a governing parameter.

Clarke and Taylor ${ }^{3}$ conducted a series of tests aimed at verifying Leonhardt's proposal. They tested 64 panels and varied the diameter and inclination of the duct as well as its stiffness. The results generally confirmed Leonhardt's provisions. 
Chitnuyanondh, ${ }^{4}$ Campbell et al., ${ }^{5}$ and Campbell and Batchelor $^{6}$ tested 52 panels. Chitnuyanondh ${ }^{4}$ reports that the strength of panels with injected cavities does not significantly differ from panels with injected steel ducts. The tested panels contained one or two ducts placed on top of one another, with spiral reinforcement around the ducts for 16 panels and without spiral reinforcement for the remaining panels. No other passive reinforcement was provided. Increasing the spacing between the two ducts increases the strength of the panel. When the spacing between ducts reaches one times the duct diameter, the strength reduction compared with a specimen with only one duct is negligible for injected ducts, but it remains substantial for empty ducts. Placing a spiral around the duct increases the strength, with a more pronounced effect for empty ducts. Unreinforced panels with an empty duct and $\delta>0.5$ had a strength $30 \%$ lower than extrapolated from Leonhardt's formula (Eq. (2)). During loading, they cracked over their whole length; the two remaining parts then failed in buckling. The authors attributed these findings to the high duct diameter to panel thickness ratio, which was outside of the parameter range of Leonhardt's investigations.

Rezai-Jorabi and Regan ${ }^{7}$ tested 15 panels and varied the duct diameter while keeping the panel dimensions constant. Their measurements of the strain distribution over the thickness of the panel confirmed observations by Leonhardt. ${ }^{2}$

Ganz et al. ${ }^{8}$ tested 14 panels with steel or HDPE ducts. The authors observed that the use of plastic ducts reduces the ultimate strength more than the use of steel ducts, although only by a small amount and in the same range as the test scatter. It must be noted that the duct diameter to panel thickness ratio was only $\delta=0.2$ in this series.

A few authors performed comparative tests on beams with tendons (stressed or not) compared with beams without tendons. $4,7,9$ The presence of inclined post-tensioning tendons, causing a favorable compression of the section and a decrease of the shear force in the web by the amount taken by the inclination of the tendon, profoundly changes the observed behavior and makes comparing structures with post-tensioning and structures without post-tensioning difficult. In spite of these difficulties, it must be noted that the observed strength reduction was much less for beams than for panels; in some cases ${ }^{9}$, beams with injected ducts even reached a higher strength than their reference beams.

\section{Summary of results from literature}

All comparable results from the aforementioned test series from the literature were compiled and formatted to allow for their direct comparison. The test results from the current study (described as follows) are also included. The results are presented as the ratio $\eta_{D}$ of the strength of the panel element with a tendon duct to the strength of an identical panel without a duct. Physically, the ratio $\eta_{D}$ is a strength reduction factor to be applied to the concrete strength, in combination with other factors (to account for cracking, size effect, and slenderness). The results are summarized in Fig. 5 (tests with spiral reinforcement omitted).

Current code provisions (from AASHTO, ${ }^{10} \mathrm{BS} 5400,{ }^{11}$ CEB-fip Model Code $90,{ }^{12}$ and EC2 ${ }^{13}$ ) are also shown in the figures. The code provisions are in the form

$$
\eta_{D}=1-k \cdot \delta
$$

The diameter correction factor $k$ is given in Table 1 for these codes.
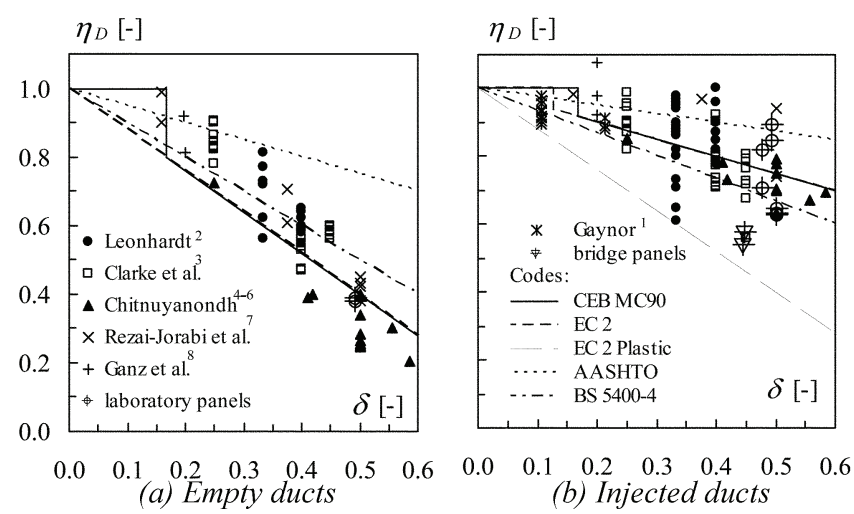

Fig. 5-Concrete strength reduction factor $\eta_{\mathrm{D}}$ for panels with post-tensioning ducts $\left(\delta=\Sigma \varnothing_{\mathrm{D}} / \mathrm{b}_{\mathrm{w}}\right)$ and corresponding code provisions.

Table 1-Diameter correction factor $k$ (Eq. (3)): current and code provisions

\begin{tabular}{c|c|c|c|c}
\hline \multirow{2}{*}{ Code } & \multirow{2}{*}{ Year } & \multicolumn{3}{|c}{$k$} \\
\cline { 3 - 5 } & & Empty & Steel & Plastic \\
\hline AASHTO & 2004 & 0.5 & \multicolumn{2}{|c}{0.25} \\
\hline BS 5400-4 & 1990 & 1 & \multicolumn{2}{|c}{0.67} \\
\hline CEB MC90 & 1993 & 1.2 & \multicolumn{2}{|c}{0.5} \\
\hline CEB MC78 & 1978 & 0.5 & \multicolumn{2}{|c}{0.5} \\
\hline EC 2 & 2004 & 1.2 & 0.5 & 1.2 \\
\hline EC 2 & 1992 & - & \multicolumn{2}{|c}{0.5} \\
\hline
\end{tabular}

As can be readily seen in Fig. 5, a significant decrease of the strength of panel elements is observed for large values of $\delta$. This decrease is stronger for empty ducts than for injected ones. In most cases, the decrease indicated by current codes is in good accordance with experimental results, with the notable exception of the AASHTO code, which underestimates the effect of the presence of the ducts.

Previous versions of the same codes did not take this effect into account, having thus a constant $\eta_{D}=1$, which was clearly unconservative. Others accounted only for a reduction of half the duct diameter, while empty ducts were not mentioned $^{15}$ or not distinguished from injected ducts. ${ }^{14}$

Regarding the loss of strength in the presence of plastic ducts, only the latest version of Eurocode 2 takes that effect into account, with a rather conservative value. This parameter should be considered in further revisions of design codes.

\section{EXPERIMENTAL PROGAM}

Within the framework of an ongoing research project on the shear capacity of thin webs containing post-tensioning tendons, two series of tests were performed on panel specimens. The first series consisted of 12 specimens cast in the laboratory, and the second consisted of four panel specimens extracted from an existing bridge built in 1967 and replaced in 2003.

The first series (laboratory panels) contained various types of ducts: empty duct (W7 and W8), injected steel duct (W5 and W6), injected HDPE duct (W1, W2, W9, and W10), duct and tendon extracted from an existing bridge (1967 steel duct; W11 and W12) (Fig. 6). Two reference panels without duct (W3 and W4) were also tested. Each panel was $23.6 \mathrm{x}$ $23.6 \times 4.9$ in. $(600 \times 600 \times 125 \mathrm{~mm})$ in dimensions (Fig. 7(a)). The laboratory specimens were provided with passive 


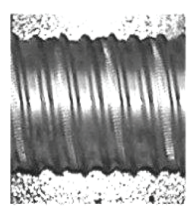

(a) Steel

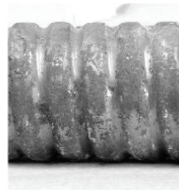

(b) Steel 1967

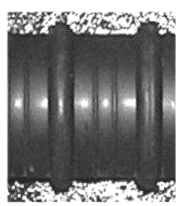

(c) $H D P E$
$\emptyset_{D}=2.44$ in. $\emptyset_{D}=2.36$ in. $\emptyset_{D}=2.48 \mathrm{in}$

$[62 \mathrm{~mm}] \quad[60 \mathrm{~mm}] \quad[63 \mathrm{~mm}]$

$t_{D}=0.02$ in. $t_{D}=0.02$ in. $t_{D}=0.08$ in

$[0.5 \mathrm{~mm}] \quad[0.5 \mathrm{~mm}] \quad[2.0 \mathrm{~mm}]$

Fig. 6-Types of ducts used in experimental program.

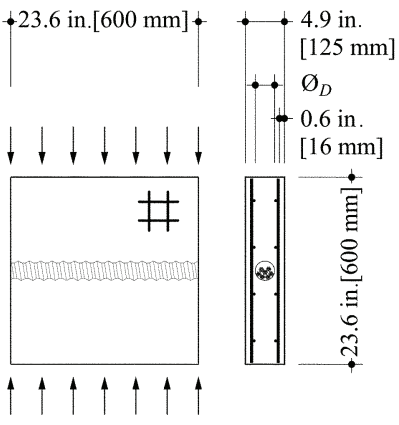

Vertical and horizontal reinforcement: \#2.5@5.9in.(Ø8@150mm) Reinforcement in the duct: 7 strands $0.6^{\prime \prime}$

(a) Laboratory panels

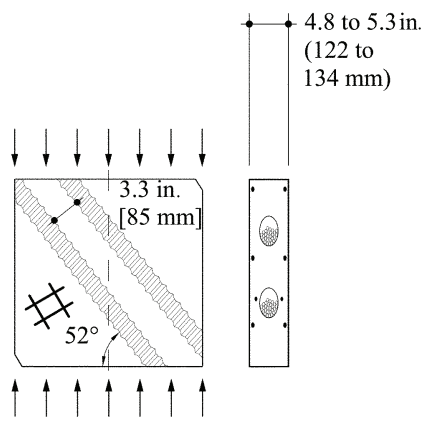

Diagonal reinforcement: \#3@7.9,\#2.5@9.8 in. (Ø10@200,Ø8@250mm)

Reinforcement in each duct: 27 wires $\varnothing 0.28$ in.(Ø7 mm)

(b) Bridge panels
Fig. 7-Geometry and reinforcement of tested specimens.

Table 2-Measured properties of passive reinforcing steel

\begin{tabular}{c|c}
\hline$f_{y}^{\prime}, \mathrm{ksi}(\mathrm{MPa})$ & $73.8(509)$ \\
\hline$f_{t}^{\prime}, \mathrm{ksi}(\mathrm{MPa})$ & $86.6(597)$ \\
\hline$f_{t}^{\prime} f_{y}^{\prime}$ & 1.17 \\
\hline$E_{s}, \mathrm{ksi}(\mathrm{MPa})$ & $29,300(202,000)$ \\
\hline
\end{tabular}

Table 3-Measured cylinder strength of concrete and injection grout at 14,21 , and 28 days ${ }^{*}$

\begin{tabular}{c|c|c|c|c}
\hline & $t$, days & 14 & 21 & 28 \\
\hline Concrete & $f_{c}^{\prime}$, psi (MPa) & $5030(34.7)$ & $5310(36.6)$ & $5410(37.3)$ \\
\hline Grout & $f_{g}^{\prime}, \mathrm{psi}(\mathrm{MPa})$ & $3920(27.0)$ & $1060(28.7)$ & $4670(32.2)$ \\
\hline *Note: Cylinder dimensions $=\varnothing / h=6.3 / 12.6 \mathrm{in} .(160 / 320 \mathrm{~mm})$.
\end{tabular}

reinforcement similar to that of the existing bridge to make a direct comparison possible. Table 2 shows the properties of the reinforcing steel used for the laboratory specimens. All specimens were cast horizontally in a single batch with a normal strength concrete $\left(f_{c}^{\prime} \cong 5200 \mathrm{psi}\left[36 \mathrm{MPa}\right.\right.$ ], $E_{c} \cong 4600 \mathrm{ksi}$ [31,500 MPa]). The maximum concrete aggregate size was 0.63 in. $(16 \mathrm{~mm})$ and the water-cement ratio $(w / c)$ was 0.55 . All specimens were tested at ages between 14 and 30 days. Table 3 gives the measured concrete strength at 14, 21, and 28 days. Seven 7 -wire-strands 0.6 in. $\left(A=7 \times 0.23\right.$ in. $^{2}[7 \mathrm{x}$

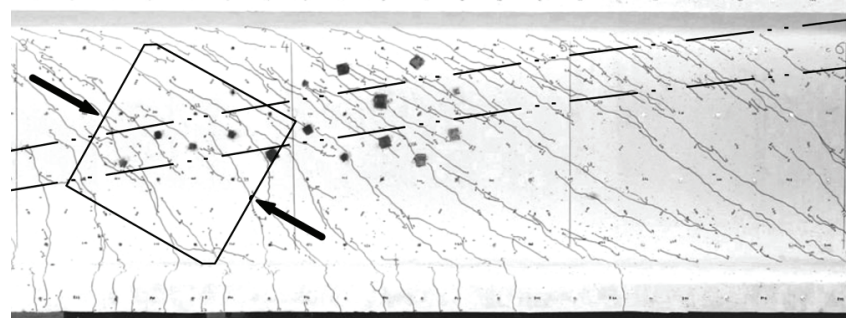

Fig. 8-Profiled I-girder with two parabolic post-tensioning cables in web (panel extraction and panel loading direction).

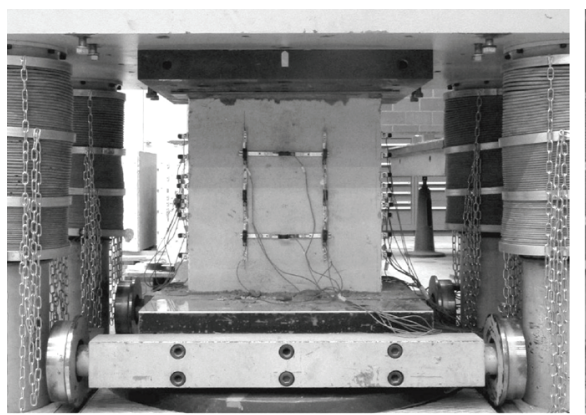

(a) Front view

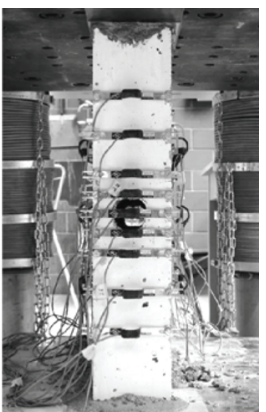

(b) Side view
Fig. 9-Specimen in testing machine with surface-mounted displacement transducers.

$\left.150 \mathrm{~mm}^{2}\right]$ ) were inserted into the ducts. Three days after casting, they were injected with non-shrink grout with a $w / c$ of 0.33 , except for Specimens W7 and W8 which were kept ungrouted. The measured grout strength $f_{g}^{\prime}$ is given in Table 3 . Specimens W11 and W12 included injected grouted tendons ducts that were extracted from beams of the existing bridge. The purpose of the inclusion of these specimens was to assess the influence of older duct types on the load-carrying capacity of thin webs and to compare the results with those from panels directly extracted from the existing bridge girders.

The second test series (bridge panels) consisted of two cracked specimens containing two tendons (1967 steel duct) placed on top of one another at a spacing of more than one duct diameter (W21 and W22, Fig. 7(b)) and two reference specimens without tendons and with no visible cracking (W23 and W24), also extracted from the existing bridge girders. The panels with tendons were cut from the bridge girder after it had been tested in the laboratory. They were thus extensively cracked, although the girder had failed in shear at the opposite side of the beam. The orientation of the panels W21 and W22 was chosen so that the shear cracks are running parallel to the direction of the loading (Fig. 8). The uncracked reference panels W23 and W24 were extracted in a vertical orientation. The amount of passive reinforcement in the bridge panels was comparable to that of the laboratory panels (Fig. 7(b)).

Table 4 shows the main parameters for all test specimens, including the estimated concrete strength at the time of testing.

Each specimen was tested in a high-capacity universal testing machine (Fig. 9), at a constant speed of $3.7 \times 10^{-5} \mathrm{in} . / \mathrm{s}$ $\left(0.9 \times 10^{-3} \mathrm{~mm} / \mathrm{s}\right)$, corresponding to approximately $0.3 \mathrm{kips} / \mathrm{s}$ $(1.3 \mathrm{kN} / \mathrm{s})$ in the linear part of the loading curve. The load was introduced through a thin 0.4 to $0.6 \mathrm{in}$. (10 to $15 \mathrm{~mm}$ ) layer of cement-based high-strength mortar placed at the 


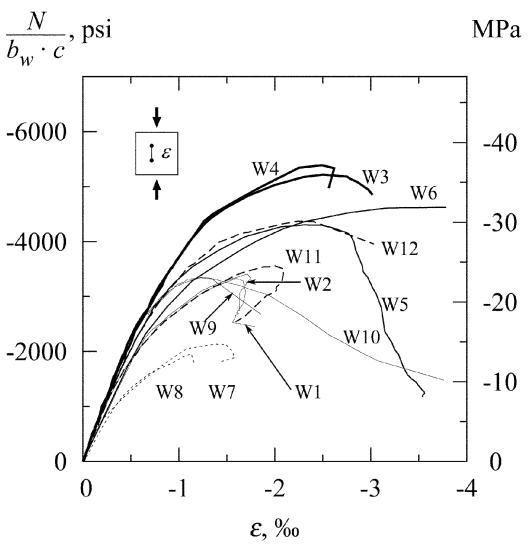

(a) Laboratory panels

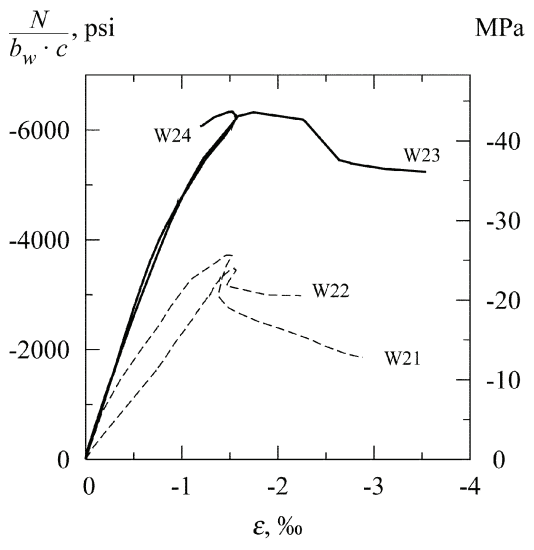

(b) Bridge panels

Fig. 10-Average compression stress versus average strain.

base and on top of the specimen. Surface measurements were made on the concrete using 34 surface-mounted displacement transducers on all sides of the specimen (Fig. 9). The measurement base was 4.9 in. (125 mm) vertically, 9.8 in. (250 $\mathrm{mm}$ ) horizontally, and $4.5 \mathrm{in} .(115 \mathrm{~mm})$ transversally, with a range of $\pm 0.08 \mathrm{in}$. [ $2 \mathrm{~mm}$ ] and a non-linearity of $1 \%$. The ambient temperature during testing was approximately $20^{\circ} \mathrm{C}$.

\section{EXPERIMENTAL RESULTS}

Figure 10 shows the stress-strain curve for all tested specimens, based on average vertical strain measurements (Fig. 9) and the applied load. The initial branch of the loaddeflection curve is linear for all specimens, followed by a loss of stiffness until the maximum load is reached. In most cases, the failure was sudden, with little or no post-peak strength. Table 4 and Fig. 11 give the ratio $\eta_{D}$ of the ultimate load carried by each specimen, after deduction of the contribution of the steel reinforcement, compared with the average strength of the two reference specimens without ducts, also after deduction of the contribution of the longitudinal reinforcement. No reduction was applied to the specimens W21 and W22 that were extracted from the existing bridge, as the passive reinforcement runs diagonally and is insufficiently anchored, thus contributing little to the load-carrying capacity.

\section{Results from laboratory panels}

Specimens W3 and W4, the two solid specimens, reached the highest load capacity, corresponding to $92 \%$ of the concrete compressive strength. This reduction results from

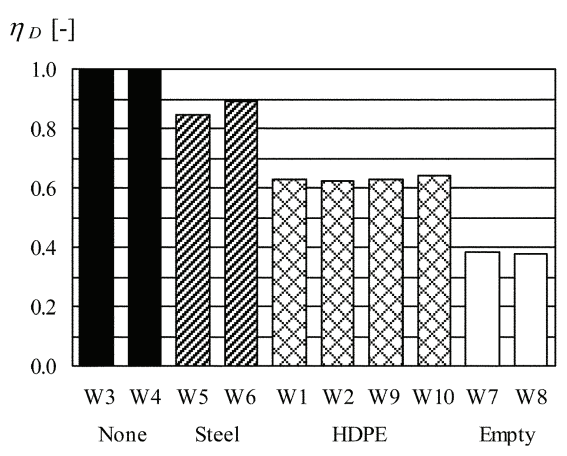

(a) Laboratory panels

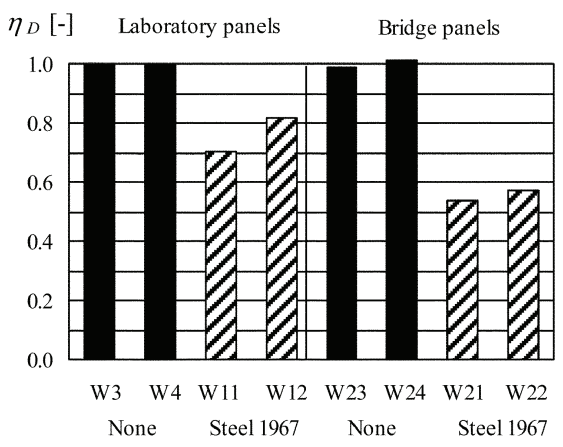

(b) Specimens with 1967 steel duct and corresponding reference panels

Fig. 11-Stress reduction factor $\eta_{\mathrm{D}}$ for tested specimens.

the slenderness of the panels and shows that the strength was not increased by local confinement effects due to friction at the loading plates. Specimens W7 and W8 with empty ducts reached the lowest value (38\% of the average strength of reference specimens W3 and W4). The largest values for specimens with injected ducts were reached by specimens with steel ducts (W5 and W6, approximately 87\%), while the specimens with HDPE ducts reached the lowest value (W1, $\mathrm{W} 2$ and $\mathrm{W} 9$, and $\mathrm{W} 10 ; 63 \%$ ). The angle of inclination $\beta$ of the duct does not seem to have influenced the strength $(64 \%$ compared with $63 \%$ ), but seems to have caused a more ductile behavior in the load-deformation response (W9 and W10). Finally, one of the specimens with tendons retrieved from an existing bridge reached values significantly lower than specimens with comparable steel ducts (W11; 71\%), probably because the injection grout was precracked by the previous loading of the tendon and by the extraction process. The other specimen with an extracted tendon reached a higher value (W12;82\%).

The measurement of the transverse expansion at the level of the tendon gives valuable information about the way inplane cracking occurs, although most cracks remain invisible to the naked eye up to high levels of loading. As Fig. 12 shows, specimens without a duct exhibited limited transverse expansion until very high levels of loading. The expansion was mainly caused by Poisson's ratio. Specimens with ducts started to diverge from the behavior of reference specimens at fairly low load levels, with a lateral expansion of $5.9 \times 10^{-3}$ to $11.8 \times 10^{-3}$ in. $(0.15$ to $0.30 \mathrm{~mm})$, mainly due to thin splitting cracks, reached at $80 \%$ of ultimate. The behavior of panels containing HDPE ducts is clearly different from the behavior of panels with steel ducts, with a more rapid development of inner cracking. It also differs from that of empty ducts. 
Table 4-Tested specimens: main parameters and results

\begin{tabular}{|c|c|c|c|c|c|c|c|c|c|c|c|c|c|c|c|c|}
\hline & \multicolumn{12}{|c|}{ First series, laboratory panels } & \multicolumn{4}{|c|}{ Second series, bridge panels } \\
\hline Specimen & W1 & W2 & W3 & W4 & W5 & W6 & W7 & W8 & W9 & W10 & W11 & W12 & W21 & W22 & W23 & W24 \\
\hline \multirow{2}{*}{ Duct } & \multicolumn{2}{|c|}{ HDPE } & \multicolumn{2}{|c|}{ None } & \multicolumn{2}{|c|}{ Steel } & \multicolumn{2}{|c|}{ Steel } & \multicolumn{2}{|c|}{ HDPE } & \multicolumn{2}{|c|}{ Steel 1967} & \multicolumn{2}{|c|}{ Steel 1967} & \multicolumn{2}{|c|}{ None } \\
\hline & \multicolumn{2}{|c|}{ Injected } & \multicolumn{2}{|c|}{-} & \multicolumn{2}{|c|}{ Injected } & \multicolumn{2}{|c|}{ Empty } & \multicolumn{2}{|c|}{ Injected } & \multicolumn{2}{|c|}{ Injected } & \multicolumn{2}{|c|}{ Injected } & \multicolumn{2}{|c|}{-} \\
\hline$\varnothing_{D}$, in. $(\mathrm{mm})$ & $\begin{array}{l}2.48 \\
(63)\end{array}$ & $\begin{array}{l}2.48 \\
(63)\end{array}$ & $\begin{array}{c}0 \\
(0)\end{array}$ & $\begin{array}{c}0 \\
(0)\end{array}$ & $\begin{array}{l}2.44 \\
(62)\end{array}$ & $\begin{array}{l}2.44 \\
(62)\end{array}$ & $\begin{array}{l}2.44 \\
(62)\end{array}$ & $\begin{array}{l}2.44 \\
(62)\end{array}$ & $\begin{array}{l}2.48 \\
(63)\end{array}$ & $\begin{array}{l}2.48 \\
(63)\end{array}$ & $\begin{array}{l}2.36 \\
(60)\end{array}$ & $\begin{array}{l}2.36 \\
(60)\end{array}$ & $\begin{array}{l}2.36 \\
(60)\end{array}$ & $\begin{array}{l}2.36 \\
(60)\end{array}$ & $\begin{array}{c}0 \\
(0)\end{array}$ & $\begin{array}{c}0 \\
(0)\end{array}$ \\
\hline$\delta$ & 0.50 & 0.50 & 0 & 0 & 0.50 & 0.50 & 0.50 & 0.50 & 0.50 & 0.50 & 0.48 & 0.48 & 0.45 & 0.45 & 0 & 0 \\
\hline Injected & Yes & Yes & - & - & Yes & Yes & No & No & Yes & Yes & Yes & Yes & Yes & Yes & - & - \\
\hline$f_{c}^{\prime}, \operatorname{psi}(\mathrm{MPa})$ & $\begin{array}{l}5278 \\
(36.4)\end{array}$ & $\begin{array}{c}5452 \\
(37.6)\end{array}$ & $\begin{array}{c}5250 \\
(36.2)\end{array}$ & $\begin{array}{c}5415 \\
(37.3)\end{array}$ & $\begin{array}{l}5076 \\
(35)\end{array}$ & $\begin{array}{c}5154 \\
(35.5)\end{array}$ & $\begin{array}{c}5352 \\
(36.9)\end{array}$ & $\begin{array}{c}5116 \\
(35.3)\end{array}$ & $\begin{array}{c}5434 \\
(37.5)\end{array}$ & $\begin{array}{l}5304 \\
(36.6)\end{array}$ & $\begin{array}{c}4984 \\
(34.4)\end{array}$ & \begin{tabular}{|c|}
5329 \\
$(36.7)$
\end{tabular} & $\begin{array}{c}7818 \\
(53.9)\end{array}$ & $\begin{array}{l}6846 \\
(47.2)\end{array}$ & $\begin{array}{l}6962 \\
(48)\end{array}$ & $\begin{array}{c}6846 \\
(47.2)\end{array}$ \\
\hline$t$, days & 22 & 30 & 21 & 28 & 16 & 18 & 25 & 17 & 29 & 23 & 14 & 24 years & 36 years & 36 years & 36 years & 36 years \\
\hline$\beta$, degree & 0 & 0 & - & - & 0 & 0 & 0 & 0 & 34 & 34 & 3 & 0 & 52 & 50 & - & - \\
\hline$N_{R}$, kips (kN) & $\begin{array}{c}386 \\
(1718) \\
\end{array}$ & $\begin{array}{c}396 \\
(1763) \\
\end{array}$ & $\begin{array}{c}607 \\
(2700) \\
\end{array}$ & $\begin{array}{c}627 \\
(2790) \\
\end{array}$ & $\begin{array}{c}501 \\
(2228) \\
\end{array}$ & $\begin{array}{c}538 \\
(2393) \\
\end{array}$ & $\begin{array}{c}248 \\
(1103) \\
\end{array}$ & $\begin{array}{c}228 \\
(1013)\end{array}$ & $\begin{array}{c}389 \\
(1733)\end{array}$ & $\begin{array}{c}388 \\
(1725)\end{array}$ & $\begin{array}{c}413 \\
(1838)\end{array}$ & $\begin{array}{c}508 \\
(2258)\end{array}$ & $\begin{array}{c}464 \\
(2066)\end{array}$ & \begin{tabular}{|c|}
433 \\
$(1924)$ \\
\end{tabular} & \begin{tabular}{|c|}
719 \\
$(3200)$
\end{tabular} & $\begin{array}{c}736 \\
(3276)\end{array}$ \\
\hline$N_{R s}$, kips $(\mathrm{kN})$ & $\begin{array}{c}29 \\
(129)\end{array}$ & $\begin{array}{c}31 \\
(139)\end{array}$ & $\begin{array}{c}46 \\
(203)\end{array}$ & $\begin{array}{c}45 \\
(202)\end{array}$ & $\begin{array}{c}42 \\
(187)\end{array}$ & $\begin{array}{c}46 \\
(205)\end{array}$ & $\begin{array}{c}27 \\
(120)\end{array}$ & $\begin{array}{l}21 \\
(91)\end{array}$ & $\begin{array}{c}22 \\
(100)\end{array}$ & $\begin{array}{c}23 \\
(100)\end{array}$ & $\begin{array}{c}36 \\
(161)\end{array}$ & $\begin{array}{c}41 \\
(181)\end{array}$ & $\begin{array}{c}0 \\
(0)\end{array}$ & $\begin{array}{c}0 \\
(0)\end{array}$ & $\begin{array}{c}23 \\
(102)\end{array}$ & $\begin{array}{l}21 \\
(94)\end{array}$ \\
\hline$N_{R c}$, kips (kN) & $\begin{array}{c}357 \\
(1589)\end{array}$ & $\begin{array}{c}365 \\
(1624)\end{array}$ & $\begin{array}{c}561 \\
(2497)\end{array}$ & $\begin{array}{c}582 \\
(2588)\end{array}$ & $\begin{array}{c}459 \\
(2040)\end{array}$ & $\begin{array}{c}492 \\
(2188)\end{array}$ & $\begin{array}{c}221 \\
(982)\end{array}$ & $\begin{array}{c}207 \\
(921)\end{array}$ & $\begin{array}{c}367 \\
(1633)\end{array}$ & $\begin{array}{c}365 \\
(1625)\end{array}$ & $\begin{array}{c}377 \\
(1677)\end{array}$ & $\begin{array}{c}467 \\
(2076)\end{array}$ & $\begin{array}{c}464 \\
(2066)\end{array}$ & \begin{tabular}{|c|}
433 \\
$(1924)$ \\
\end{tabular} & \begin{tabular}{|c|}
696 \\
$(3098)$ \\
\end{tabular} & $\begin{array}{c}715 \\
(3182)\end{array}$ \\
\hline$\frac{N_{R c}}{b_{w} \cdot c}, \mathrm{psi}(\mathrm{MPa})$ & $\begin{array}{c}3072 \\
(21.2)\end{array}$ & $\begin{array}{l}3140 \\
(21.6)\end{array}$ & $\begin{array}{c}4829 \\
(33.3)\end{array}$ & $\begin{array}{c}5005 \\
(34.5)\end{array}$ & $\begin{array}{c}3946 \\
(27.2)\end{array}$ & $\begin{array}{c}4231 \\
(29.2)\end{array}$ & $\begin{array}{c}1900 \\
(13.1)\end{array}$ & $\begin{array}{c}1781 \\
(12.3)\end{array}$ & $\begin{array}{c}3158 \\
(21.8)\end{array}$ & $\begin{array}{c}3142 \\
(21.7)\end{array}$ & $\begin{array}{c}3242 \\
(22.4)\end{array}$ & $\begin{array}{l}4015 \\
(27.7)\end{array}$ & $\begin{array}{c}3720 \\
(25.6)\end{array}$ & $\begin{array}{l}3479 \\
(24)\end{array}$ & $\begin{array}{c}6117 \\
(42.2)\end{array}$ & $\begin{array}{c}6153 \\
(42.4)\end{array}$ \\
\hline$\frac{N_{R c}}{b_{w} \cdot c \cdot f_{c}^{\prime}}$ & 0.58 & 0.58 & 0.92 & 0.92 & 0.78 & 0.82 & 0.35 & 0.35 & 0.58 & 0.59 & 0.65 & 0.75 & 0.48 & 0.51 & 0.88 & 0.90 \\
\hline$\eta_{D}$ & 0.63 & 0.62 & 1.00 & 1.00 & 0.84 & 0.89 & 0.38 & 0.38 & 0.63 & 0.64 & 0.71 & 0.82 & 0.54 & 0.57 & 0.99 & 1.01 \\
\hline
\end{tabular}

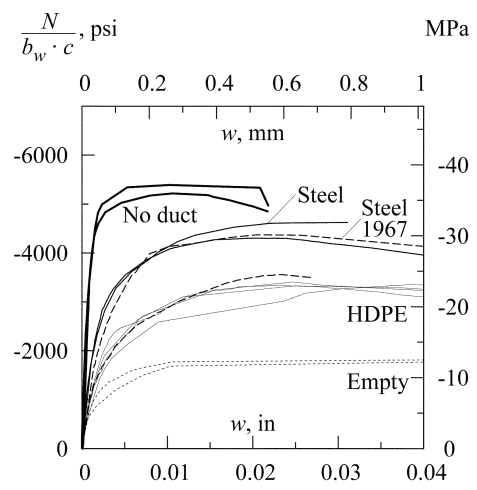

(a) Laboratory panels

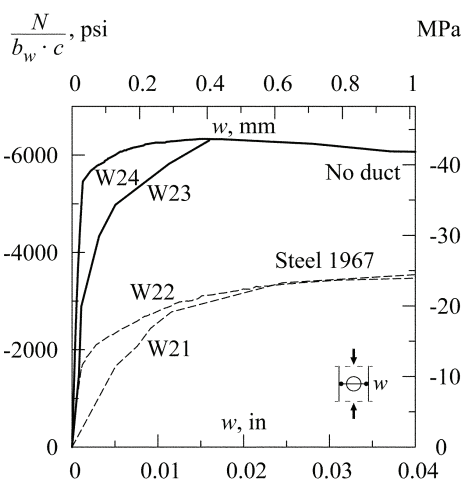

(b) Bridge panels

Fig. 12-Average compression stress versus transverse expansion at duct location.

Shortly before the ultimate load was reached, splitting cracks became visible on the side faces. At the ultimate load, the specimen was almost split in two parts (Fig. 13). On the front faces, no cracking was observed before the ultimate load, except for specimens with empty ducts, for which cracks appeared at approximately $70 \%$ of ultimate.

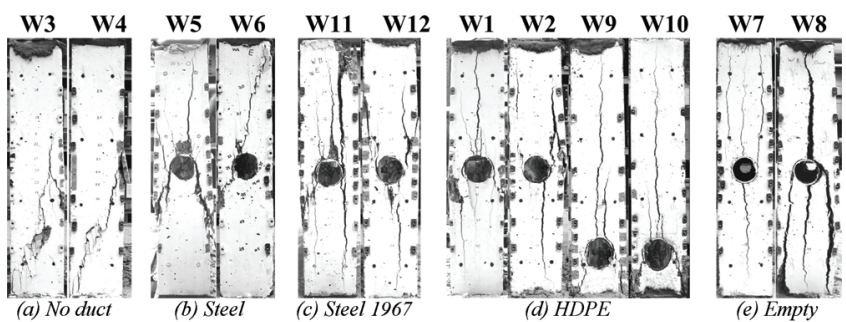

Fig. 13-Side surfaces of laboratory panels after testing.

\section{Results from bridge panels}

The stress-strain curve, the strength reduction factor $\eta_{D}$ and the transverse elongation measurements of the bridge panels are shown in Fig. 10(b) to 12(b), respectively. Their behavior was similar to that of the laboratory panels. The two cracked specimens with tendons reached $56 \%$ of the strength of their reference panels, much lower than the laboratory specimens with injected steel ducts.

This reduction is mainly caused by the previous loading in shear and the resulting cracks parallel to the compression field (Fig. 8). Using the strength reduction factor by Vecchio ${ }^{16}$

$$
\frac{f_{c e}}{f_{c}^{\prime}}=\frac{1}{1+0.27 \cdot\left(\frac{\varepsilon_{1}}{-\varepsilon_{p}}-0.37\right)}
$$

one can estimate the reduction in strength caused by the transverse strains from the testing of the bridge, which were measured at approximately $\varepsilon_{1}=3.5 \%$, and taking $\varepsilon_{p}=-2 \%$, to approximately $0.7 f_{c}^{\prime}$.

Assuming that the same deformation $\varepsilon_{1}$ would have been imposed to Specimens W11 and W12, their strength would have been reduced by a factor 0.73 , yielding $\eta_{D}$ values of 0.52 and 0.60 , respectively, which compare very well with 
the average measured ratio of 0.56 measured on the cracked panels W21 and W22.

The measured transverse expansion of the reference bridge panels W23 and W24 was similar to that of the reference laboratory panels W3 and W4. The bridge panels exhibited a much softer behavior, likely caused by the precracking imposed by the previous loading of the panels (Fig. 12). The transverse crack pattern after testing of Specimens W21 and $\mathrm{W} 22$ is similar to that of panels W11 and W12. The fact that two tendons were present in the panels does not appear to have had a significant effect.

\section{Proposal for code improvement}

Based on the observed behavior from both laboratory and bridge panels, the authors propose that a strength reduction in the form of $\eta_{D}=1-k \cdot \delta$ be applied with $k$ being equal to 0.4 for steel ducts, 0.8 for plastic ducts, and 1.2 for empty ducts. These values are valid for normal-strength concrete elements.

The effect of the more stringent requirements implied by the findings of the present study may be somewhat mitigated in practical cases by the fact that the shear strength of webs of post-tensioned girders is not necessarily limited by the strength of the compressive struts, but rather by the tensile strength of the stirrups. In critical cases, the disposition of a suitable reinforcement transverse to the web in the vicinity of the tendon can prevent this mode of failure without requiring other design changes.

\section{SUMMARY AND CONCLUSIONS}

Two series of 12 and four specimens of web panels have been tested in the laboratory to investigate the effect of duct type and of web cracking on the ultimate compressive strength of web girders crossed by post-tensioning tendons. The ratio of the diameter of the duct to the thickness of the web was approximately 0.5 . For that value, the observed loss of strength was significant, comparable for panels with steel ducts to values obtained in previous studies - approximately $13 \%$. Panels with HDPE plastic ducts had a much larger loss of approximately $37 \%$.

Precracked panels extracted from an actual bridge with steel tendons exhibited a much lower strength than initially uncracked laboratory panels without tendons (loss of approximately 44\%), the difference being attributed to the effect of cracking on the concrete strength. The influence of the type of steel duct (1967 versus current) is not significant.

Current code provisions mostly give a correct estimate of the loss of compressive strength of the compression struts in the presence of steel ducts, with the exception of AASHTO, which underestimates this effect.

Only the Eurocode 2 explicitly distinguishes between steel and plastic ducts. Based on the observed behavior from the tested panels, the authors propose that a strength reduction in the form of $\eta_{D}=1-k \cdot \delta$ be applied for normal-strength concrete, with $k$ being equal to 0.4 for steel ducts, 0.8 for plastic ducts, and 1.2 for empty ducts.

\section{ACKNOWLEDGMENTS}

The authors want to acknowledge the gracious support and funding of the Swiss Federal Roads Authority which made the experimental and theoretical studies possible and VSL International for providing post-tensioning material for the laboratory specimens.

\section{NOTATION}

$A \quad=$ area

$b_{w} \quad=$ web thickness; panel element thickness $c \quad=$ side dimension of panel element

$E_{c} \quad=$ modulus of elasticity of concrete

$E_{H D P E}=$ modulus of elasticity of high-density polyethylene

$E_{S} \quad=$ modulus of elasticity of passive reinforcement

$f_{c}^{\prime} \quad=$ concrete cylinder strength

$f_{c e}=$ effective concrete strength in presence of transverse strains

$f_{g}^{\prime}=$ grout cylinder strength

$f_{t}^{\prime} \quad=$ tensile strength of passive reinforcement

$f_{y}^{\prime} \quad=$ yield stress of passive reinforcement at $0.2 \%$ offset

$k=$ diameter correction factor

$N=$ compression force on panel element

$N_{R} \quad=$ ultimate load of panel element

$N_{R c}=$ portion of ultimate load carried by concrete

$N_{R s}=$ portion of ultimate load carried by passive reinforcing steel; estimated on basis of concrete surface strain measurements

$t \quad=$ age

$t_{D} \quad=$ duct wall thickness

$w \quad=$ transverse expansion

$\beta=$ tendon angle of inclination relative to normal to compression strut

$\delta=$ ratio of total width of all ducts to panel thickness in critical section

$\varepsilon=$ strain

$\varepsilon_{1} \quad=$ maximum concrete strain

$\varepsilon_{p} \quad=$ reference concrete strain at peak stress $(-2 \%$ o

$\eta_{D}=$ strength reduction factor

$\Sigma \varnothing_{D}=$ sum of duct diameters in critical section

$\varnothing_{D}=$ duct diameter

\section{REFERENCES}

1. Gaynor, R. D., "Effect of Horizontal Reinforcing Steel on the Strength of Molded Cylinders," ACI Journal, Proceedings V. 62, No. 7, July 1965, pp. $837-840$

2. Leonhardt, F., "Abminderung der Tragfähigkeit des Betons infolge stabförmiger, rechtwinklig zur Druckrichtung angeordnete Einlagen (Reduction of Concrete Compressive Strength due to Rods Inserted Perpendicularly to the Loading)," Festschrift Rüsch, Berlin, Germany, 1969, pp. 71-78. (in German)

3. Clarke, J. L., and Taylor, H. P. J., "Web Crushing-A Review of Research," Technical Report, Cement and Concrete Association, London, 42-509, 1975, $16 \mathrm{pp}$

4. Chitnuyanondh, L., "Shear Failure of Concrete I-Beams with Prestressing Ducts in the Web," $\mathrm{PhD}$ thesis, Queen's University, Kingston, Canada, 1976, 245 pp.

5. Campbell, T. I.; Batchelor, B.,; and Chitnuyanondh, L., "Web Crushing in Concrete Girders with Prestressing Ducts in the Web," PCI Journal, V. 24, No. 5, 1979, pp. 71-87.

6. Campbell, T. I., and Batchelor, B., "Effective Width of Girder Web Containing Prestressing Duct," Journal of the Structural Division, ASCE, V. 107, 1981, pp. 733-744.

7. Rezai-Jorabi, H., and Regan, P. E., "Shear Resistance of Prestressed Concrete Beams with Inclined Tendons," The Structural Engineer, V. 64B, No. 3, 1986, pp. 63-75.

8. Ganz, H. R.; Ahmad, A.; and Hitz, H., "Load Transfer through Concrete Sections with Grouted Ducts," Report 242e, VSL, Bern, Switzerland, 1992, 20 pp.

9. Fairbairn, E. M. R., and Trinh, J. K. L., "Influence des Câbles Relevés sur la Résistance de l'Ame des Poutres Soumises à des Actions TangentesEtudes Expérimentales (Influence of Inclined Post-Tensioning Cables on the Web Strength of Girders Subjected to Tangential Loads-Experimental Studies)," I.T.B.T.P Annals, No. 400, Series B 203, Paris, France, 1981, pp. 14-20. (in French)

10. AASHTO, "AASHTO LRFD Bridge Design Specifications," 3rd Edition, Washington, D.C., 2004, 1450 pp.

11. BS 5400-4:1990, "Steel, Concrete and Composite Bridges-Part 4: Code of Practice for Design of Concrete Bridges," London, 1990, 79 pp.

12. Comité Euro-International du Béton (CEB), "CEB-FIP Model Code 1990," Thomas Telford Publishing, London, 1993, 460 pp.

13. EUROCODE 2, "Design of Concrete Structures-Part 1-1: General Rules and Rules for Buildings," CEN, EN 1992-1-1, Brussels, Belgium, 2004, 225 pp.

14. Comité Euro-International du Béton (CEB), "CEB-FIP Model Code for Concrete Structures," Information Bulletin, 124/125-E, Paris, France, 1978, 348 pp.

15. EUROCODE 2, "Design of Concrete Structures-Part 1-1: General Rules and Rules for Buildings," CEN, prENV 1992-1-1, Brussels, Belgium, 1992, $252 \mathrm{pp}$.

16. Vecchio, F. J., "Disturbed Stress Field Model for Reinforced Concrete: Formulation," Journal of Structural Engineering, ASCE, V. 126, No. 9, 2000, pp. 1070-1077. 